\title{
Women Leadership and its Relevance to National Development in the 21st Century
}

\author{
Emily Oghale God's Presence \\ http://dx.doi.org/10.4314/ujah.v15i2.8
}

\section{Abstract}

The involvement of the female persons in nation-building is an ineluctable right as well as inescapable reality for a holistic and comprehensive political development, economic and social advancement in the $21^{\text {st }}$ century national polity. Female gender is naturally imbued with salient and sterling leadership qualities. Women are also known to be resilient family and society builders. Over time in history, a few women who have been entrusted with the leading role to manage human and material resources have more often than not proved the same point that, given adequate backing, they can perform creditably. This study enunciates the historical dateline of women's quest for a chance in leadership and nation-building; few examples of women in leadership positions and their immense and exemplary contributions to societal polity and nation-building are spotlighted.

\section{Introduction}

It is pertinent to state that the wake of the $21^{\text {st }}$ century has birthed the long awaited desire of women to be in the corridors of power, to be vocal about their needs, and to execute their dreams by contributing their quota to national development. The universal emphasis on women's contributions to society resulting from the world-famous 
conference that was held in Beijing China in 1995 has obviously revealed the undeniable influence of women to national development. Although the awareness about the relevance and undeniable role of women gained momentum in the late 1980's, it was further enhanced at the United Nations Fourth World Conference on Women held in Beijing in 1995. The conference which serves as an eye-opener to all women has become a launch-pad into the $21^{\text {st }}$ century where women leadership has spread through all spheres and sectors of society.

In reminiscing the previous efforts of women towards leadership and the struggle for equal rights with men, Barry writes that the "women's movement" of the 1960s, in the Western world "was not the start of feminism, rather, it was a renewal of an old tradition of thought and action already possessing its classic books which had diagnosed the problem of women's inequality in society and in some cases, proposed solutions" (qtd. in Okerri 35).

Suffice it to state that it is not only in the Western world that women have caught the wind of their rights and importance to society development. Looking down memory lane, it is glaring that the ever-green Aba women's riot of 1929, which was a well organized and successful protest against imperialists unconstitutional imposition of taxation on women in the Eastern part of Nigeria, stamps out the so called cliché that women are the "weaker sex" and as such of no impact. History has shown that women all over the world have worked hard to arrive at this point in the $21^{\text {st }}$ century where they are gradually rising into positions of power in all sectors of society. The undeniable contributions of women to national development have led to the conclusion that was made by Caldwell that:

Indeed, when women are full participants in the democratic process, there is greater likelihood 
that a society's policies will better reflect the needs of all its citizens. Beyond that, a 2005 report from the U.N's Millennium Project notes that, when women are well represented on governing bodies, the overall quality of governance tends to rise and levels of corruption $\operatorname{sink}(2)$.

The fact that the female gender is naturally imbued with such salient and sterling qualities as industry, meticulousness, peaceloving, economy, risk management, perseverance, shrewdness, shock absorbing, leadership skills, organizational skills, human and material management skills, to mention but a few, cannot be overemphasized. Women are also known to be resilient family and society builders. Over time in history, a few women who have been entrusted with the leading role to manage human and material resources have more often than not proved the same point that, given adequate backing and free hand, they can exceed normal expectations. Women leaders have demonstrated less cantankerous attitude to conflict management than men who would often display a showmanship of ego which often result in escalation of tensions that eventually leave the defenceless women and children population at the suffering end. Women leaders have also demonstrated utilitarianism and more honesty in statecraft-ship than the male gender that can easily sacrifice probity on the stable of corruption, ultra vires exercise of power, avariciousness for "filthy lucre," and sometimes demonstrate abysmal insensitivity to the plight, sentiments and sufferings of the silent and voiceless majority in society.

\section{Gender Discrimination and Women's Struggle}

As a sequel to the aforementioned scenarios of women's previous effort to attaining positions of power, this work will throw some light on the various forms of discrimination the 
female gender has suffered as well as their struggles for their rights, which simply translated is 'power with authority.'

Having grown up in a culture where female subjugation begins right from childhood, my personal experience as a pupil and student becomes relevant to this study. In the primary schools, girls were either seated together or they sit in the front rows while the boys sit at the rear. This scenario is commonly seen in orthodox churches, even till now where the female folk sit on one side and the males on the other. In subject choices at the secondary school level, females were restricted from certain subject areas. For example, Agricultural Science was exclusively a male preserve while Home Economics/Home Management was for the female students. It is shocking to note that, even at the wake of $21^{\text {st }}$ century, males (including teenagers) often deny females of all age grades the right to sit by the car door, and they would rather step out for the female gender to sit inside, even if they were already seated before the arrival of a female passenger. Worse still, if a female person was already seated by the door, a male would want her to move in or ask her to make any adjustment to his convenience. This is the height of discrimination and denial of women's right to sitting in a position of their choice. This is indeed a violation of women's right, and it is little wonder that Bessie Head laments that:

The ancestors made so many errors and one of the most bitter-making things was that they relegated to men a supervisor position in the tribe, while women were regarded, in congenital sense, as being an inferior form of human life. To this day, women still suffered from all the calamities that befall an inferior form of human life (qtd. in James 5). 
Gender discrimination is an artificial creation by male hegemony to perpetuate their egoism. The recognition by women that denial of their participation in national development equals the denial of their rights has evolved the establishment of Non-Governmental Agencies (NGOs) as avenues to fight discrimination and to make their grievances known. Thus Okoh affirms that the belief that "women's rights are human rights" have been gaining ground all over the world in the last few decades. She however refers to the United Nations Universal Declaration of Human Rights in 1948, which is also applicable to Nigeria, as stated by Laqueur and Rubin (1979) that, "All human beings are born free and equal in dignity and rights and freedoms set forth therein: without distinction of any kind including distinction based on sex" (qtd. in Okoh 10).

Women's struggles for positions, as an affirmation of their rights as human beings and as bona fide citizens of their country have left some indelible marks on their families. For example, Kudirat Abiola was gruesomely murdered as a result of her political ambition after her husband's death who suffered political victimization when the office of the president was denied him after having won the presidential June 12 election of 1993. A similar example of women's struggle and painful experiences is Benazir Bhutto's painful demise on $27^{\text {th }}$ December 2007, at an active age of 54 as she contend for the presidency in Pakistan where she was shot dead after she returned from a self-imposed exile for 8 years after her first phase of leadership in the same capacity when she took over from her father. It is interesting to note that Benazir was sworn in as Pakistan's first woman to head the Islamic State of Pakistan on December, 2, 1988.

The struggle for leadership positions and the attendant problems of gender discriminations are very obvious to women. This scenario has made Bene Madunagu to regret that 
in Nigeria, some positions are strictly reserved for the male gender. In Nigeria, the positions of the president and vice president are exclusively male preserves, unlike other countries like Chile, Liberia, India, Argentina, etc., where women are Executive Presidents. Madunagu regrettably puts forward her observation in this manner:

The Nigerian President and Vice-President are both men. (The Nigerian ruling class could not even pretend to concede the position of "Vice-" to a woman as they do in many institutions.) Nigeria is divided into 19 states and the political head of each state - the governor - is a man. Of the 449 Seats in the House of Representatives, very few are occupied by women. There are 95 Senators - all male! The Chief Justice of the Federation is a man, etc., etc. Thus, even on the level of the bourgeois concept of women's emancipation, Nigerian society is still men's exclusive domain - at least on the level of government (135).

The issue of equal rights and power sharing, especially in leadership positions, has become the paramount objective on feminists' agenda. It is true that some women have gained positions of recognition, but are they given the authority to function independently or they are still monitored by the males and tailored towards the expectations of a patriarchal society? How many women are in positions of authority today?

\section{Overview of Women Leadership Globally}

Looking back over the years, one would never have imagined that women would rise to leadership positions globally, especially in Africa where women's dreams and 
aspirations are often frustrated and submerged by an oppressive patriarchal culture. Women in key positions around the world especially in Nigeria who deserve to be mentioned will be looked at in this work; because according to Marjorie "MO" Mowlam, a member of British parliament, "it is important for women to not just be in office, but in power. Women must be in power before we can be said to be equal" (qtd. in Wilson 33).

\section{Nigerian Women in Leadership and their Contributions}

The awareness for women to rise and run for elective political and top management offices in the socio-economy has been gaining crescendo in recent times. Emily God'spresence observes that

Despite the enormity of the chasm created between men and women as a result of the marginalization Nigerian women are facing today, feminists' cry for gender equity and women empowerment is subtly and steadily raising women's consciousness to rise above the force of patriarchy that has heretofore submerged them in low self-esteem, making them complacent and indifference to leadership roles, especially in politics. Despite the fact that women have not yet been given the opportunity to be President, Vice President or Governors (except for Etiaba's historic attainment in 2007), women are determinedly, gradually and systematically, taking their place in society, making their presence known in whatever small capacity they find themselves by showing their worth through their numerous achievements. (50). 
God's presence however observes that few women have dared political leadership in Nigerian politics, hoping to become governors or president. With the giant strides made by women over the years and recently in Nigeria through the advocacy of feminists, it is pertinent that their contributions to the Nigerian society in all sectors of national development be the subject of discourse. Despite the fact that the prestigious positions of the Governor, President and Vice-president have been exclusively male preserve, some women have attained the positions of Deputy Governors in some States of the Federation. Only in 2006 was history made in Nigerian politics when Virgy Etiaba, the then Deputy Governor of Anambra State broke the jinx by sheer luck or chance when she briefly occupied the position of the executive governor of Anambra State for a few months and later returned to her former post as deputy when Peter Obi was reinstated as Executive Governor of Anambra State.

A catalogue of Nigerian women who have contributed to national development include Fidelia Njezie (former Minister of Aviation), who only in a short while exploited her ingenuity to resuscitate the aviation sector from its collapsing state. Hajia Ruqayya A. Ruffai, current Minister of Education, has given education a new dimension; Farida Waziri, the boss of Economic Financial Crimes Commission (EFCC) up until 2011, has brought sanity to the body polity of the nation by exposing some corrupt leaders to justice. Dora Akunyili, former Director General of National Agency for Food and Drug Administration and Control (NAFDAC), made sure that the proliferation of illicit and expired drugs was curtailed, thereby saving lives and health of innocent citizens; she championed the arrest and detention of many fake drug peddlers and manufacturers as well as confiscated and destroyed detected fake and dangerous drugs wherever they were found in the country. She was also the Minister for 
Information in the 2007-2010 dispensation when she initiated her "Re-branding Nigeria Campaign."

Ngozi Okonjo-Iweala, as the former minister of finance during President Obasanjo's regime, helped to turn around the debt regime of Nigeria by negotiating the cancellation of debt which Nigeria owed the International Monetary Fund (IMF) and Paris Club. She has been the Managing Director of World Bank, and recently has been appointed by President Goodluck Ebele Jonathan as Nigeria's Minister of Finance and Coordinating Minister for the Federal Republic of Nigeria (2011). Since 2007, her counterpart, Obiageli Ezekwesili popularized the due process office of the presidency in Nigeria during President Olusegun Obasanjo's regime. Obiageli Ezekwesili was the World Bank vice President for Africa Region whose tenure ended in 2012. It is also on record that Justice Aloma Mukhtar in 2012 was appointed the Nigeria's first female Chief Justice of the Federation by President Goodluck Ebele Jonathan's administration. The appointment was based on her credible track record in the judiciary.

Going back to history, a few women have demonstrated sterling leadership qualities in their societies. According to Tolani Animashaun, Nigerian women were actively involved in political leadership before the colonial incursion into our land:

Long before British colonial administration and the struggle for independence, some women in the parts of the territory later designated Nigeria played political roles in Nigeria. There are well-documented accounts of women's roles in pre-colonial Nigeria. For instance the IGALA was said to have been founded by a women named EBELE EJAUNU. In IJESHA in Yoruba land, five of the thirty-eight OBA (kings) had been women. Prominent among Northern 
Kings or Queens was Queen AMINA of ZARIA who in the 15 th century

extended her influence as far as NUPE. The role of UMU ADA in the East and Niger Delta as civil society organizers, were very significant. These groups had control of markets and ensured that standards were followed. In Bonny, Queen KAMBASSA of Bonny was perhaps the only female AMANYANABO of Bonny. The rise of Mrs. OLUFUMILAYO RANSOME KUTI, as an Icon in the Nigeria political arena can probably be attributed to her early incursion into Western education. And was showcased to some extent in the recent musical Fela where her political influence was very apparent. Also Mrs Margaret Ekpo contributed significantly to the politics of the colonial period and she worked for equal enjoyment of civil rights for Nigerians in the colonial era where Europeans accorded themselves priority status (qtd. in God'spresence 47-48).

On women's remarkable leadership and their notable heroic effort towards improving humanity, (pre-dating the emergence of Mary Slessor), it is pertinent to cite the example of the queen mother, the Iyoba Ede of Uselu in Benin (Nigeria). The leadership of the queen mother (mother of King Eresonyen) in the $18^{\text {th }}$ century (early 1700 to 1750 ) is noteworthy. According to the Women leaders in Africa: worldwide guide to women in leadership, 2009, the Iyoba Ede of Uselu

successfully fought the rebellious chiefs and restored power and legitimacy to the Benin Monarchy. As Queen Mother she was a senior 
town chief. She lived in her own palace outside the capital. She did not appear in public and did not have an official role in the political system, but she was always "consulted" by important political decisions, and her vote was necessary in the political decision process (qtd. in God'spresence 48).

If Nigeria were no less a patriarchal society then in the $18^{\text {th }}$ and $19^{\text {th }}$ centuries than it is now, and has never been matriarchal, yet notable women doggedly fought to make a difference in a domain that is termed an exclusive preserve of males, one wonders why Nigerian women in this $21^{\text {st }}$ Century, with all the women empowerment programmes, feminist discourses and propaganda, should be less represented in prestigious positions and making decisions that impact nation building. It is interesting to note that women undauntedly found their way into the political arena and made exploits in the $20^{\text {th }}$ century. According to Melisende

In 1957 during the pre-independence era of Nigeria, a couple of women political activists such as, Mrs. Margaret Ekpo, Mrs. Janet Mokelu and Ms. Young were members of the Eastern House of Assembly. The late Mrs. Funmilayo Ransome-Kuti, though not a full-fledged politician, was a very strong force to reckon with in the politics of the Western Region. And Hajia Gambo Sawaba waged a fierce battle for the political and cultural emancipation of women in the North.The Babangida era marked a turning point in the history of women struggle in Nigeria, when Maryam Babangida institutionalized the office of the first lady in 1987. She became the first working First Lady and launched the "Better 


\section{Life for Rural Women" program (qtd. in God'spresence 49).}

From the few examples enumerated above it is obvious that the advocacy for equality of rights and power sharing among the sexes, which are the main aims of feminism have been gaining attention. This aligns with Helen Chukwuma's advocacy that "there is the need for women to take their rightful places in society beside and alongside their men, not behind them groaning in silence" (xvi).

An outstanding example of a woman who has "taken the bull by the horn" to take her rightful place, walking side by side men is Patience Goodluck Jonathan, the wife of the Nigeria's president. Patience, having attended international conferences where she compared notes with other female nationals and international leaders, returned home with the campaign of $35 \%$ Affirmative Action. This campaign advocates that $35 \%$ of Nigeria's women be given political appointment to align with what was agreed upon at the Beijing Women's Conference of 1985 in women's world conference in Beijing, China. She further launched her pet project "Women for Change Initiative and Development Agenda" which she inaugurated in Abuja, Nigeria, on July 16, 2010. She took a further step by travelling round the 36 states of the federation, lobbing for women participation in politics as well as campaigning for her husband, Goodluck Jonathan, in the April 2011 Presidential election. She woes all women to vote massively for her husband as president and promises their involvement and participation in leadership up to $35 \%$.

Patience Goodluck Jonathan is indeed a woman of substance and she has confirmed the saying that "what men can do, women can do, even better." Her campaign paid off and today her husband won the presidential election of April 2011 and was sworn into office on May 29, 2011 as Nigeria's 
democratically elected president; consequently, women participation and involvement in leadership is beginning to increase in number by the day. Thus, the observation of Marie Wilson is timely when she states:

\begin{abstract}
All of my adult life I have preached the virtues of power sharing between men and women. The arrangement seemed not only fair, but also obvious: Women populate half the democracy; we should occupy half the positions of leadership both for gender equity and because women, a natural resource should be mined for energy (ix).
\end{abstract}

\title{
Conclusion
}

Whereupon it has been discussed earlier in this study that all inclusive government is in the best public interest, it goes without gainsaying that women make an appreciable workforce. To reiterate Zarrin Caldwell's observation, evidence has shown that allowing women to participate fully in governance and democratic process would increase the likelihood that a society's policies will better reflect the needs of all its citizens. Additionally, a 2005 report from the U.N's Millennium Project notes that when women are well represented on governing bodies the overall quality of governance tends to rise and levels of corruption sink. History reveals that in comparison, women tend to show more zero tolerance to corruption than men, and this fact translates well in leadership.

The shrewdness which women express in conducting home and family affairs is an eloquent testimony that given a cooperative hand to join freely in societal governance and political leadership, women have got worthwhile and tested experience to draw from. Also, there are track records of scores of women who have held their societies spell-bound 
by the type of excellent leadership they have offered in service to their people. Many of these women, some of whom are cited as examples earlier in this work, have done so well as leaders in the educational, management, economic and social sectors. So, the onus rests on the larger society to encourage and engage the full participation and contribution of women in national development generally and in leadership especially.

The nation(s) would be losing a vital factor in nationbuilding without active and full involvement of women. Besides, many men-leaders have hopelessly failed on the mandate of the people that brought them to power; so it is time that women be generously allowed to wear the leadership cap since it seems to suit them more appropriately, because whereas most societies led by male authoritarianism and patriarchal hegemony have often suffered from totalitarian and abysmal corruption, women leadership conversely have often benefitted their societies and nations by demonstrating zero tolerance to corruption.

\section{Emily Oghale God's Presence Department of theatre Arts Faculty of Humanities University of Port Harcourt}




\section{Works Cited}

Animashaun, Tolani. Nigerian women in politics. In Emily O. God'spresence. A feminist critical appraisal of the theme of women leadership in cinema: A study of selected nollywood films. Unpublished Ph.D Dissertation. University of Port Harcourt 2012.

Barry, Peter. Beginning theory: An introduction to literary and cultural theory $\left(2^{\text {nd }} e d.\right)$. Manchester: Manchester University Press, 2002.Print.

Head, Bessie. A question of power. In James, Adeola. (Ed.). In their own voices: African women writers talk. London: James Currey Ltd.,1990. Print.

Caldwell, Zarrin T. Women and governance: A place at the table. 2006. 9 February, 2008 $<$ http://en.wikipedia.org/wiki/leadership >.

Chukwuma, Helen (Ed.). Feminism in African literature: Essays on criticism. Enugu: New Generation Books, 1994. Print.

God'spresence, Emily Oghale. A feminist critical appraisal of the theme of women leadership in cinema: A study of Nollywood films. Ph.D Diss. U. of Port Harcourt, 2012. Print.

James, Adeola. (Ed.). In their own voices: African women writer's talk. London: James Currey Ltd, 1990. Print.

Madunagu, Bene E. Contemporary positions and experiences of women. London: Women in Nigeria Today (Third World Books), 1985. Print.

Melisende. Nigerian women crucial to politics. Women of history.

<Womenofhistory.blogspot.com> November 30, 2008. January 11, 2012.

Okerri, Emily Oghale. The self-sacrificing mother image in Nigerian video films: A critical analysis of selected works. M.A. Thesis. U of Port Harcourt, 2006. Print. 
Okoh, Julie. Theatre and women's human rights in Nigeria. Port Harcourt: Pearl Publishers, 2002. Print.

Wilson, Frederica. (Panelist). "Propelling Women Forward in your Community." United Way 2004 Summit on Women in Philanthropy, Chicago, Ill, 2004. Print

Wilson, Marie C. Closing the leadership gap: Why women can and must help run the world. New York: Penguin Group, 2004. Print.

Women Leaders in Africa: worldwide guide to women in leadership.

$<$ http://www.guide2womenleaders.com/womeninpowe r/Africa.htm> August 15, 2009. January 7, 2013. 